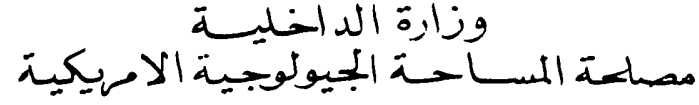

DEPARTMENT OF THE INTERIOR

UNITED STATES GEOLOGICAL SURVEY

$(y)$ (

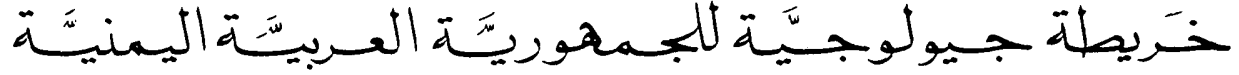

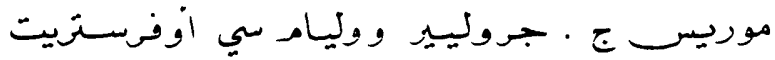

\title{
GEOLOGIC MAP OF THE YEMEN ARAB REPUBLIC (ŞAN'A')
}

By Maurice J. Grolier and

William C. Overstreet

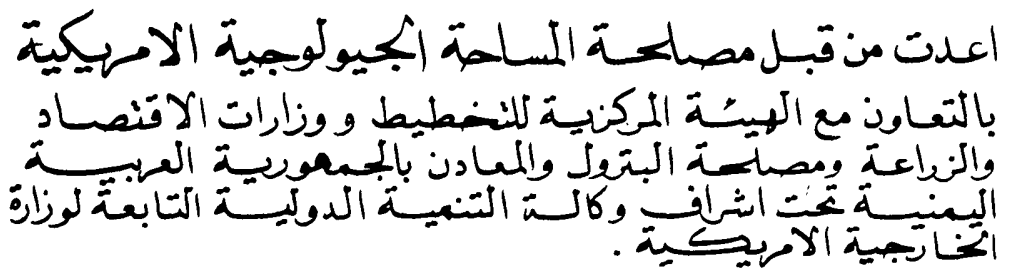

PREPARED BY THE U.S. GEOLOGICAL SURVEY

IN COOPERATION WITH THE CENTRAL PLANNING ORGANIZATION,

THE MINISTRIES OF ECONOMY AND AGRICULTURE, AND THE

MINERAL AND PETROLEUM AUTHORITY OF YEMEN ARAB

REPUBLIC, UNDER THE AUSPIECES OF THE AGENCY FOR

INTERNATIONAL DEVELOPMENT, U.S. DEPARTMENT OF STATE

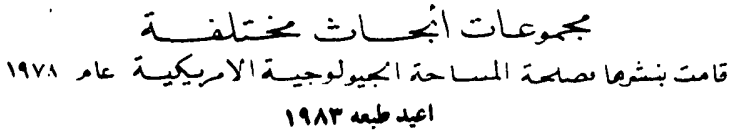

MISCELLANEOUS INVESTIGATIONS SERIES

Published by the U.S. Geological Survey 1978

Reprinted, 1983 